Available online on 15.07.2018 at http://jddtonline.info
Journal of Drug Delivery and Therapeutics
Open Access to Pharmaceutical and Medical Research
$\begin{gathered}\text { O 2011-18, publisher and licensee JDDT, This is an Open Access article which permits unrestricted non- } \\ \text { commercial use, provided the original work is properly cited }\end{gathered}$

Open Access

Review Article

\title{
Role of Panchakarma in Various Disorders Associated with Pain; W.S.R. to Sciatica, Spondylitis and Osteoarthritis
}

\author{
Dr Ashish Mishra ${ }^{*}$, Dr Pankaj Nigam² \\ ${ }^{1}$ Reader, Panchkarma Dept., Dr Anar Singh Ayuvedic Medical College and Hospital, Farrukhabad (UP) India. \\ ${ }^{2}$ Lecturer, Panchkarma Dept., Veena Vadini Ayurvedic College and Hospital, Kolar, Bhopal, India.
}

\begin{abstract}
Ayurveda is a system of medicines practicing in India anciently. The concepts and belief of ayurveda based on logical reasoning and experimental observations. Ayurveda not only mentioned approaches of disease prevention but also described preventive measure to maintain good health status. The therapeutic measures of ayurveda not only involves use of medicine but also utilizes other approaches such as; Panchakarma. Panchakarma is a Shodhana Chikitsa and approved as vital therapy for the management of various disorders. Panchakarma offer various therapeutic benefits such as; detoxification, improved circulation, relief spasm and pain. The efficacy of Panchakarma also well proven in pain related diseases. This article presented role of Panchakarma in pain W.S.R. to Sciatica, Spondylitis and Osteoarthritis.
\end{abstract}

Keywords: Ayurveda, Panchakarma, Shodhana Chikitsa, Shoola roga, Sciatica.

Article Info: Received 10 June, 2018; Review Completed 13 July 2018; Accepted 14 July 2018; Available online 17 July 2018

Cite this article as:

Mishra A, Nigam P, Role of Panchakarma in Various Disorders Associated with Pain; W.S.R. to Sciatica, Spondylitis and Osteoarthritis, Journal of Drug Delivery and Therapeutics. 2018; 8(4):362-364 DOI: $\underline{\text { http://dx.doi.org/10.22270/jddt.v8i4.1809 }}$

*Address for Correspondence:

Dr Ashish Mishra, Reader, Panchkarma Dept., Dr Anar Singh Ayuvedic Medical College and Hospital, Farrukhabad (UP) India.

\section{INTRODUCTION}

Panchakarma is one of the purification method described by ayurveda which help to detoxify body. Panchakarma involve utilization of five sub-therapies which help to maintain normal health status. Panchakarma maintain Tridoshic balances, maintain circulatory process, impart calmness, improve tonicity, boost internal strength and purify whole body therefore offer relief in various diseases. The Shaman \& Shodhan Chikitsa of Panchakarma pacify vitiated Doshas and normalizes functioning of Dhatu. Snehana and Swedana are preparatory steps of Panchakarma (Poorva Karma) which initiate body for main procedure; Pradhan Karma $1-3$

Diseases which are associated with pain mainly involve localized symptoms and vitiated Vata dosha. Panchakarma therapy help to relief localized symptoms associated with pain such as; inflammation, swelling and strain. Panchakarma also pacifies Vata dosha therefore help in diseases such as; Sciatica, Spondylitis and Osteoarthritis. Panchakarma therapies such as; snehana, swedana, vamana, virechanai, basti and shirovirechan help to manage painful diseases as mentioned above.

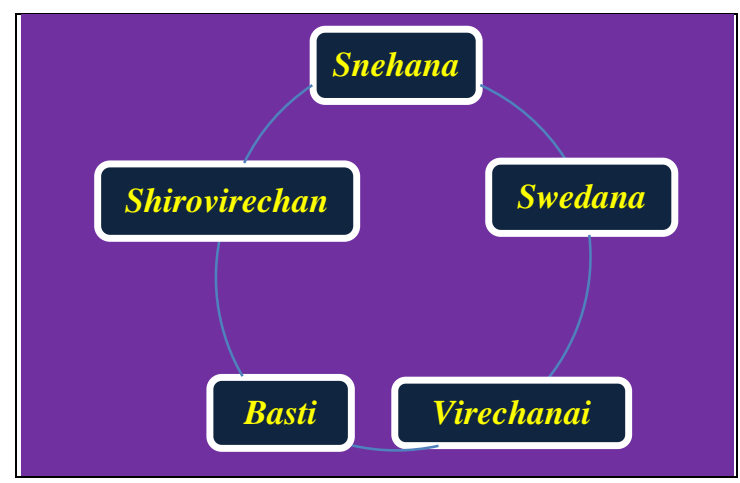

Figure 1: Panchakarma approaches for various Shoola roga. 


\section{Panchakarma for Sciatica}

Sciatica is associated with disturbance of sciatic nerves of leg. In Ayurveda it is termed as gridhrasi and mainly involves vitiation of Vata Dosha. Pain around hip, thigh, back and lower leg, muscles strain and pricking sensation are the symptoms of disease. Panchakarma recommended for gridhrasi along with other medication and exercise. Sedated oils used in Panchakarma help to calm sciatic nerve. Panchakarma in gridhrasi may perform as follows:

* Snehana: Application and sprinking of oil over the most affected area.

* Swedana: Pizichil, sudation with oil and upanaha sweda in gridhrasi.

* Mridu samshodhana: Mridu Virechana in controlled manner.

* Shiravyadha/Rakta-mokshana: Recommended to perform 4 angula above knee joint.

Kati Basti is also recommended for lower back pain and therefore may be utilized in sciatica. The well of flour mixture loaded with warm oil applied over lower back, warm oil help to expands vessels, relax muscles, offer calming effect, enhance recovery process and alter rigidity.

Matra Basti possessing Snigdha, Laghu, Ushna and Tikshna guna therefore offer Vata-Kapha Shamaka activity. Pacify Kapha and Vata, Snigdha Guna of Taila antagonizes Ruksha of Vata while Tikshna Guna pacifies Srotodushti, therefore Matra Basti control Apan Vayu thus relief pain in sciatica. Vasti purify Purishadhara Kala and Asthi Vaha Srotas while Sneha Basti possesses Vata Shamaka property. Vasti removing Mala and Avarana thus help to clears Srotas. The Snigdha Guna of oils normalizes Apan Vayu which and relief pain of sciatica.

* Panchakarma procedure such as; Snehana and Svedana boost muscle tone.

* Vasti with Tikta and Madhura Rasa drugs offer antiedematous and anti-inflammatory properties.

* Shalishastika Pinda Svedana offer nourishment to muscles and bones thus reduces inflammation and pain.

\section{Panchakarma for Osteoarthritis}

Osteoarthritis is a degenerative joint disease causing pain, swelling and restricted joint motion. Osteoarthritis involve loss of cartilage mainly affects joint of hands, knees and hips. Tenderness, stiffness, loss of flexibility and grating sensation are the others symptoms of disease. The persons of middle or higher age affecting more than younger one while female are more susceptible to disease than male. Ayurveda recommended use of Panchakarma therapy for the symptomatic relief of disease. Snehana and Swedana with Dashamoola taila and Dashamoola kwatha offer vatashamaka, balya and anulomaka properties thus help in Sandhigata vata. The Panchakarma therapy increases joint space temporarily and improves movement \& flexibility of joints. The Snehana and Swedana help to maintain body tonicity therefore strengthening muscle, ligament and tendon flexibility.

- Abhyanga: Abhyanga pacifies vata, reduces pain, strengthens muscles and improves joints flexibility.

- Janu basti: Janu basti lubricate fluid in joint and maintain integrity of the bony frame, boost blood circulation, nourishes knee joints and enhance mobility of knee joints.

- Sveda: Sveda helps to keep joint warm, reduces stiffness and pain, relaxes muscle and provide symptomatic relief in osteoarthritis.

- Virechana: Virechana eliminate vitiated doshas and possess vata anulomana. Thus relief pain and stiffness of osteoarthritis.

\section{Panchakarma for Spondylitis}

$>$ Snehan involving massage with external oil followed by massage with medicated oil which pacifies vata and soften body. Sesame oil and draksha decoction may be used internally.

$>$ Swedana soften the srotas, liquefy the doshas and remove aggravated vata. Swedana impart calming effect, relax and prepare body for further main procedure of Panchakarma.

$>$ Basti is very useful in painful disorders predominant of vata, anuvasana and niruhana basti advised for the management of shoola. Snehan and swedana followed by asthapana basti with decoction of pippali, bilwa, devadaru and madanphala remove vitiated vata thus relief pain.

$>$ Shirovirechana not directly affect clinical manifestation of spondylitis but it help to manage pain and irritability up to some extent. It offers calming, relaxing and pain curbing properties. Jyotishmati kshavaka, vidanga, shigru, apamarga, sarshapa, tandula and sweta recommended for shirovirchana. Shirovirchana also relief burning sensation around neck area associated with spondylitis.

$>$ Nasya with Anu Taila also help in spondylitis. 
Table 1: Panchakarma and related approaches for the management of pain related disorders:

\begin{tabular}{|c|c|c|c|}
\hline Therapy & Procedure & Effect & Indication \\
\hline Pizhichil & $\begin{array}{l}\text { Medicated oil is poured onto the } \\
\text { body in continuous streams while } \\
\text { being gently massaged }\end{array}$ & $\begin{array}{l}\text { A soothing and } \\
\text { relaxing }\end{array}$ & $\begin{array}{l}\text { Vata dominant } \\
\text { ailments }\end{array}$ \\
\hline Abhyangam & $\begin{array}{l}\text { Whole body massage with specific } \\
\text { herbal oils }\end{array}$ & $\begin{array}{l}\text { Reduces stress and } \\
\text { induces sleep }\end{array}$ & $\begin{array}{l}\text { To relief muscles } \\
\text { spasm and pain }\end{array}$ \\
\hline Kativasthi & $\begin{array}{l}\text { Warm oil kept over the lower back } \\
\text { using natural edge of natural } \\
\text { material. }\end{array}$ & Relieves pain. & $\begin{array}{l}\text { Indicated in low back } \\
\text { pain and Spondylitis }\end{array}$ \\
\hline Kizhi & $\begin{array}{l}\text { Herbal leaves / powders applied to } \\
\text { the whole body with hot medicated } \\
\text { oils }\end{array}$ & $\begin{array}{l}\text { Relieves pain and } \\
\text { oedema }\end{array}$ & $\begin{array}{l}\text { Indicated in arthritis } \\
\text { and spondylosis. }\end{array}$ \\
\hline Nasyam & $\begin{array}{l}\text { Herbal juices and medicated oils } \\
\text { applied through the nostrils. }\end{array}$ & $\begin{array}{l}\text { Improve circulation, } \\
\text { open channels and } \\
\text { clean passages. }\end{array}$ & $\begin{array}{l}\text { Relieve headaches, } \\
\text { sinusitis and } \\
\text { spondylosis. }\end{array}$ \\
\hline Sirovasthi & $\begin{array}{l}\text { Medicated oils kept on the head for } \\
\text { a particular period of time. }\end{array}$ & $\begin{array}{l}\text { Reduces stress, relax } \\
\text { body, and diminishes } \\
\text { pain sensation and } \\
\text { offer calming effect. }\end{array}$ & $\begin{array}{l}\text { Used for headache } \\
\text { and disorders. }\end{array}$ \\
\hline
\end{tabular}

\section{REFERENCES}

1. Dr. S.G. Huparikar, Dr. V.P. Jogalekar, Textbook of Agadtantra, Ist Edition, Rashtriya

Shikshan Mandal Pune, Lecture, 2008; 7: 35.

2. Susruta Samhita Sutra (26/10), Ayurved Tattva Sandipika Hindi Commentary by Ambika Datta Shastri (2001), 12th edi, Chaukhambha Sansakrit Sansthan Varanasi.

3. Sushruta samhita, Shastri AD. $11^{\text {th }}$ ed. Varanasi: Chaukhambha Academy; 1997. Ayurvedic approach for management of ankylosing spondylitis: A case report.

4. Pandey G., editor. Pt. Kashinath Sastri Vidhyotini Hindi Commentarator of Charaka Samhita of Agnivesa. Vol. 2. Chaukumba Sanskrit Sansthan; Varanasi: 2006. p. 1096. (Sidhi Sthan Uttarvastisidhi Adhayay). Ch. 12, Ver. 15.

5. Singh S.K., Rajoria K. Ayurvedic approach in the management of spinal cord injury: a case study. Anc Sci Life. 2015; 34:230-234.

6. Mishra S., editor. Sidhiprada Hindi Commentary on Bhaisajyaratnavali. Chaukhamba Surbharati Prakashan; Varanasi: 2007. pp. 535-536. Vatvyadhirogadhikara. Ch. 26, Ver. 198-202.
7. Brahmasankar M., editor. Vidhyotini Hindi commentary on Bhavprakash Nighantu. Gudichayadivarg.10th ed. Chaukhambha Sanskrit Sansthan; Varanasi: 2002. p. 393. Ch.3, Ver. 190.

8. Ayurveda Sara Sangraha. 12th ed. Sri Vaidhyanath Ayurveda Bhavan Limited; Allahabad: 2007. Rasa Rasayan Prakarana; pp. 309-310.

9. Brahmasankar M., editor. Vidhyotini Hindi Commentary on Bhavprakash Nighantu. Gudichayadivarg.10th ed. Chaukhambha Sanskrit Sansthan; Varanasi: 2002. p. 298. Ch. 3, Ver. 62-63.

10. Ratanakar Yog, Tripathy Indaradev, Dr, Tripathy D.S., Dr . Vatavyadhi Chikitsa. 1st edition. 294. Vol. 293. Varanasi: published Krishnadas academy; 1998. p. 427.

11. Shastri Rajeswardatta, Upadhaya Yadunandana., editors. Ch. Chi. 37. Vol. 28. Varanasi: published by Chaukhambha Bharti Academy; Charaka, Charaka samhita Vidyotini Hindi Commentary; p. 783.

12. Nidana Madhava. In: M. Ni. Thirteenth edition. 21. Upadhaya Yadunandana., editor. Vol. 22. Varanasi: published by Chaukhambha Sanskrit Sansthan; 2002. p. 463. 